\title{
Agricultura urbana em Lisboa: uma leitura histórica e uma perspetiva de futuro ${ }^{1}$
}

\author{
Flora Del Debbio \\ floradeldebbio@gmail.com \\ Arquiteta, Itália
}

Para citação: DEL DEBBIO, Flora - Agricultura urbana em Lisboa: uma leitura histórica e uma perspetiva de futuro. Estudo Prévio 18. Lisboa: CEACT/UAL - Centro de Estudos de Arquitetura, Cidade e Território da Universidade Autónoma de Lisboa, 2020, p. 37-56. ISSN: 2182-4339 [Disponível em: www.estudoprevio.net]. DOI: https://doi.org/10.26619/2182-4339/18.5

Artigo recebido a 1 de outubro de 2020 e aceite para publicação a 13 de dezembro de 2020 . Creative Commons, licença CC BY-4.0: https://creativecommons.org/licenses/by/4.0/

\section{Resumo}

O presente artigo procura refletir sobre o modo como a interpenetração entre espaço urbano e espaço rural se constitui como uma das características marcantes da cidade de Lisboa ao longo da sua história. Recorrendo a fontes primárias como antiga documentação escrita e cartografia histórica, procura-se mapear de forma detalhada a ocupação agrícola no solo citadino. O equilíbrio que foi sendo mantido, ao longo dos séculos, entre espaço construído e espaço cultivado, é quebrado com o advento da Revolução Industrial e com a consequente crescente pressão urbana, levando à ocupação das zonas mais periféricas, sem que sejam consideradas a natureza do solo e dos antigos terrenos produtivos. Importa hoje reconhecer e tirar partido das singulares características climáticas e morfológicas do lugar que, ao longo da história, criaram as condições favoráveis à prática agrícola no território, na óptica de uma mais consciente gestão dos recursos naturais e dos espaços verdes, por forma a reencontrar a proximidade entre consumidor e produtor, perdida nos últimos séculos.

Palavras-Chave: Lisboa, agricultura, produção, urbano, rural 


\title{
Urban agriculture in Lisbon: historical reading and future perspective
}

\begin{abstract}
This article intends to retrace how the permeability between urban and rural space has historically distinguished the city of Lisbon. Through the use of primary sources, such as old written documents and historical cartography, this text aims to trace in detail the past agricultural occupation of the city soil. Particularly, the balance established over the centuries between built and cultivated space failed with the Industrial Revolution, when the structure of the old city was overturned by a growing urban pressure that would have led to the occupation of the more peripheral areas, without considering the nature of the soil and of the ancient productive lands. The particular climatic and morphological characteristics of the site, that have historically fostered the agricultural practice on the territory, must be recognized and employed today envisaging a more conscious management of natural resources and green spaces, in order to restore the proximity between consumer and producer that was lost in the last century.
\end{abstract}

Palavras-Chave: Lisbon, agriculture, production, urban, rural

\begin{abstract}
"Ainda hoje, o vale de Chelas, por exemplo, conserva no meio da cidade uma curiosa feição campestre [...] O vale é, na sua quase totalidade, agricultado: olivais, vinhas, hortas. Daí vem alguma da hortaliça que Lisboa consome." (RIBEIRO, 1994 [1935]: 14)
\end{abstract}

\section{Origens da atividade agrícola em Lisboa}

Dada a sua particular condição geográfica e morfológica, a cidade de Lisboa apresenta, desde o seu primeiro ciclo de urbanização, uma forte componente agrícola, que a tem acompanhado ao longo da sua evolução. O aglomerado urbano não cresceu de forma concêntrica, mas antes em articulação com as linhas estruturantes de colinas, separadas por longos vales onde se acumulavam as águas pluviais que tornavam os seus terrenos férteis e aptos para um uso agrícola do solo (RIBEIRO, 1949: 4). Esta particular condição natural do lugar levou a que não houvesse uma distinção clara entre centro histórico e periferia rural e criou as condições para que, ao longo da história, houvesse uma proximidade entre consumidor e espaço produtivo acabou por refrear a progressiva polarização entre cidade e campo que marcou a maioria das capitais europeias nos últimos séculos. Deste modo, a atividade agrícola enquanto fonte primária de abastecimento de alimentos não estava completamente relegada para os territórios exteriores à cerca da cidade, tendo antes lugar ao longo dos fecundos vales que penetravam até ao centro da cidade e lhe conferiam um carácter rústico muito particular: "em torno do núcleo relativamente compacto, constituído pelo monte do Castelo, a Baixa e as suas cercanias, formaram-se digitações em vários sentidos, deixando entre si extensas áreas desaproveitadas - os seus grandes vazios" (RIBEIRO, 1994 [1935]: 16).

Ao longo dos séculos, a imagem da capital foi sendo profundamente marcada por este 
cunho campestre, conforme demonstram a cartografia histórica, mas também as descrições da antiga cidade, que denotam um interesse particular pelas práticas agrícolas desenvolvidas dentro e fora da cerca muralhada (Figura 1). Na Lisboa antiga, campo e cidade coexistiam, sendo que urbe e ager eram entidades distintas ainda que não independentes, que faziam parte de um mesmo sistema: hortas, pomares e olivais penetravam, assim, através dos vales férteis confundindo-se com o espaço edificado (TELLES, 2011a: 98-99).

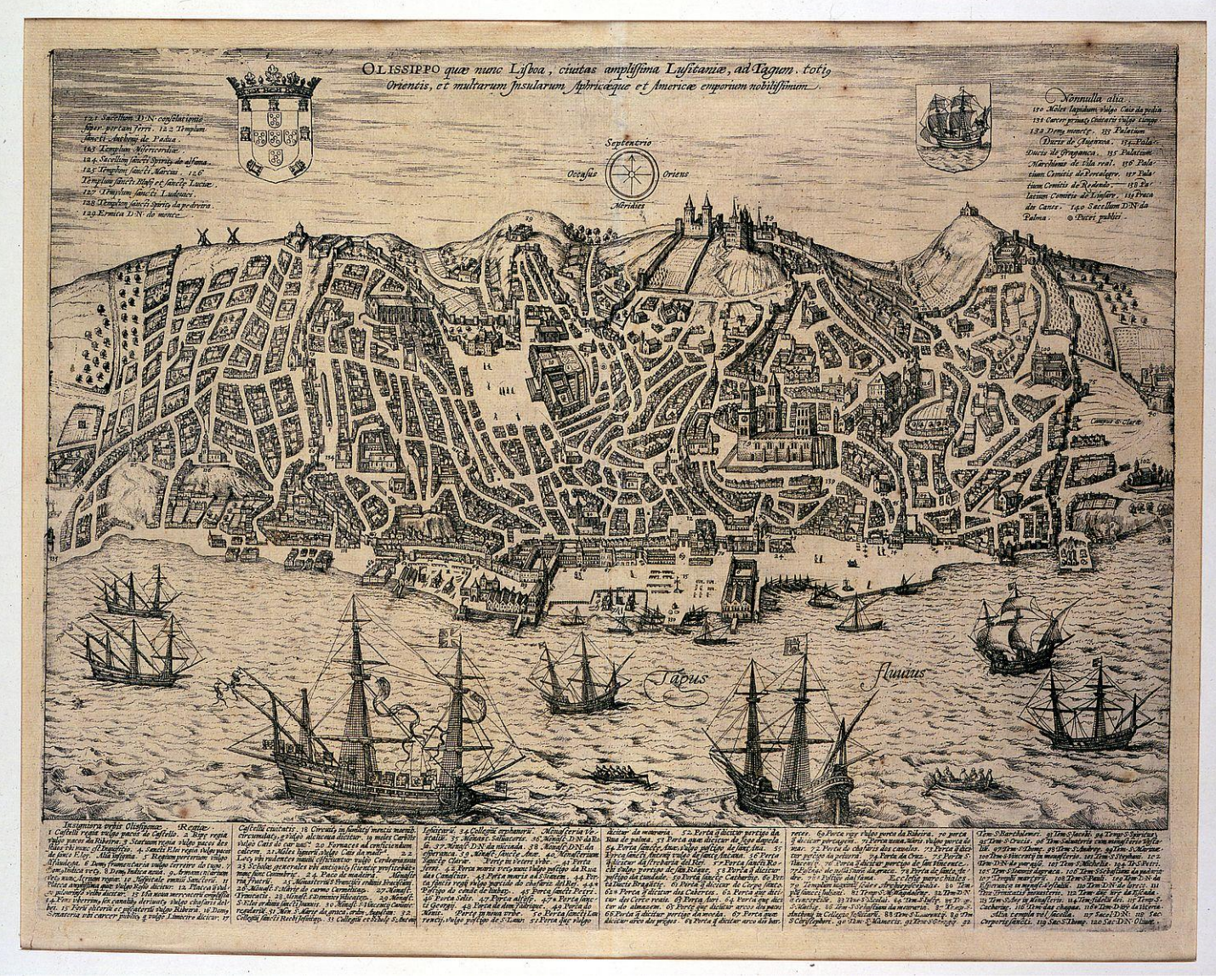

Figura 1 - Vista de Lisboa em perspetiva aérea. Xilografia de 1593. Autor: Franz Hogenberg. Fonte: Museu de Lisboa. Disponível em:

http://www.museudelisboa.pt/pecas/detalhe/news/perspetiva-de-lisboa.html

Depois do domínio romano², os árabes, que conquistaram a península em 711 d.C., deixaram a sua marca na paisagem cultivada, transmitindo conhecimentos em matéria agrícola e introduzindo inteligentes sistemas de irrigação, alguns deles ainda hoje em uso (TELLES, 1997: 41). O cultivo de hortícolas era então uma prática comum, desenvolvida nas hortas ou almuinhas das zonas limítrofes ${ }^{3}$ que asseguravam a alimentação da população já numerosa de Lisboa. Recorrente nas mais antigas descrições da cidade, o termo "almuinha", de origem árabe, foi usado com frequência, a par do termo "horta", até ao século XII, momento em que começa lentamente a cair em desuso, depois da expulsão dos Mouros da cidade de Lisboa (AZEVEDO, 18991900: 215). Referia-se a uma espécie de horto murado, e era definido no Elucidário das palavras, termos e frases que em Portugal antigamente se usaram e que hoje 
PT | P01 | EP18| w2021

regularmente se ignoram (1798) como "Horta fechada sobre si, terra de pomar, parreiras, e hortaliças, frutos, hervas, e arvores, que servem de matar a fome" (VITERBO, 1798: 102-103). Os árabes, que tinham contribuído para a promoção do conhecimento no campo agrícola no território português, legaram um vasto léxico relativo à agricultura e aos sistemas hidráulicos: o termo chafariz, que significa fonte, é utilizado ainda hoje na linguagem comum, tal como a palavra nora, que designa uma máquina hidráulica utilizada para retirar água de poços ou cisternas (AZEVEDO, 18991900: 268).

\section{Condições naturais do lugar: clima e geomorfologia do território}

Ao longo dos séculos, a produção agrícola abundante na região de Lisboa ficou a dever-se a condições naturais particularmente favoráveis como a fertilidade do terreno, a abundância de água e o clima, amenizado pela presença do estuário (RIBEIRO, 1994 [1935]: 26). No século XVII, Frei d'Oliveyra referia-se a "boa terra, boa agoa, bom clima" (D'OLIVEYRA, 1804: 261) como sendo os ingredientes fundamentais à agricultura e que garantiam saúde aos habitantes da cidade, cuja dieta era principalmente composta por produtos frescos de produção local (D'OLIVEYRA, 1804: 260-261). O autor de Do sítio de Lisboa, afirmava ainda, referindo-se à capital:

"Considerando primeiro a fertilidade do seu Termo, naõ sei se haja no Mundo outro mais fertil, porque naõ ha terra, que melhor produza o que nella se semêa, se planta, nem outro igual destricto que sustente tanta Povoações, e casas. E esta he a maior prova da sua fertilidade; porque qual terra ha no Mundo, que tendo os seus campos tão habitados, como as Cidades, tenha substancia para manter a gente que nella, e no seu destricto habita?". (Vasconcelos, 1786: 131)

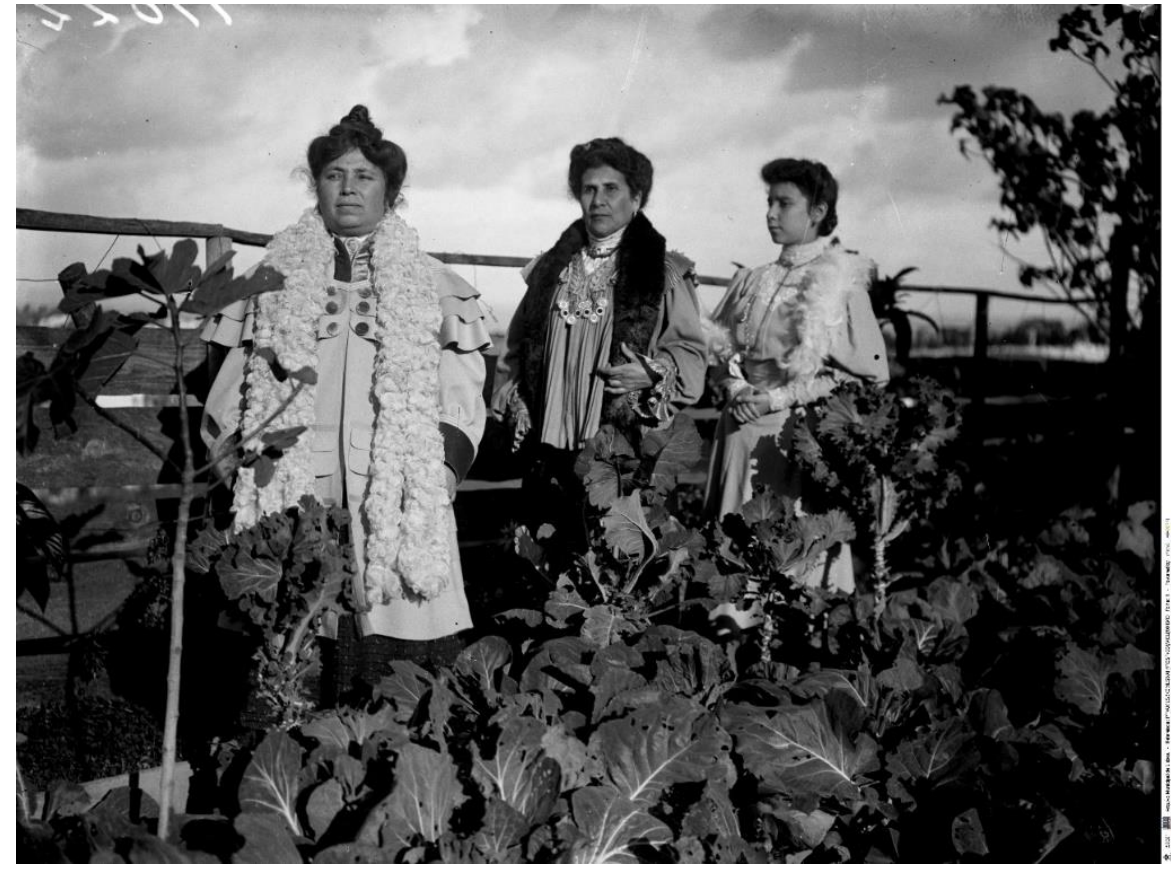

Figura 2 - Senhoras numa horta, 191?. Fonte: Arquivo Fotográfico Municipal de Lisboa, PT/AMLSB/ACU/001910. 
O naturalista alemão Heinrich Friedrich Link, que visitou Lisboa no final do século XVIII, mostrou-se impressionado com as singulares condições geomorfológicas do território e pelo modo como estas eram favoráveis à actividade agrícola. As fecundas colinas de basalto situadas na zona ocidental da cidade destinavam-se a culturas mais extensivas de trigo, cevada e centeio. De facto, com a erosão do tempo, a rocha basáltica transforma-se numa argila fértil que, irrigada naturalmente pelas chuvas, se revela particularmente adequada à exploração agrícola (LINK, 2005).

No que respeita à parte oriental da cidade, encontramos na revista $O$ Arqueólogo Português um excerto da obra do geólogo Choffat, O Passeio geológico de Lisboa a Leiria, publicada no final do século XIX, em que o autor descreve a geomorfologia do planalto do Campo Grande (ou Alvalade) e do vale que se desce do Areeiro até à Baixa. No planalto, a leve pendente não permitia que se acumulasse muito húmus no fundo, pelo que predominavam culturas extensivas de vinha, cereais e árvores de fruto, que se estendiam de modo uniforme sobre toda esta superfície argilo-calcária. No limite do planalto, junto ao Areeiro, formava-se uma depressão que se estendia até ao centro da cidade e chegava até à zona do Rossio. O maciço argilo-arenoso do fundo do vale funcionava como uma grande esponja capaz de reter um volume considerável de águas pluviais: "A abundancia de agua permitia o grande aproveitamento de todo este terreno da parte oriental de Lisboa na cultura intensiva das hortas" (AZEVEDO, 1899-1900: 215) que se estendiam desde a zona da Mouraria, até à Praça do Rossio e à Praça da Figueira, e mesmo até Xabregas, por talhões em que a água era captada e distribuída através de poços e fontes. A utilização de eficientes sistemas hidráulicos e a natureza particularmente fértil dos terrenos fizeram destas zonas "as fornecedoras das hortaliças consumidas pela cidade de Lisboa" (AZEVEDO, 1899-1900: 215), garantindo a proximidade entre produtor e consumidor. As condições particulares do solo determinaram assim que as culturas intensivas se concentrassem na zona oriental, enquanto que na zona ocidental da cidade se desenvolvia uma agricultura de tipo extensivo.
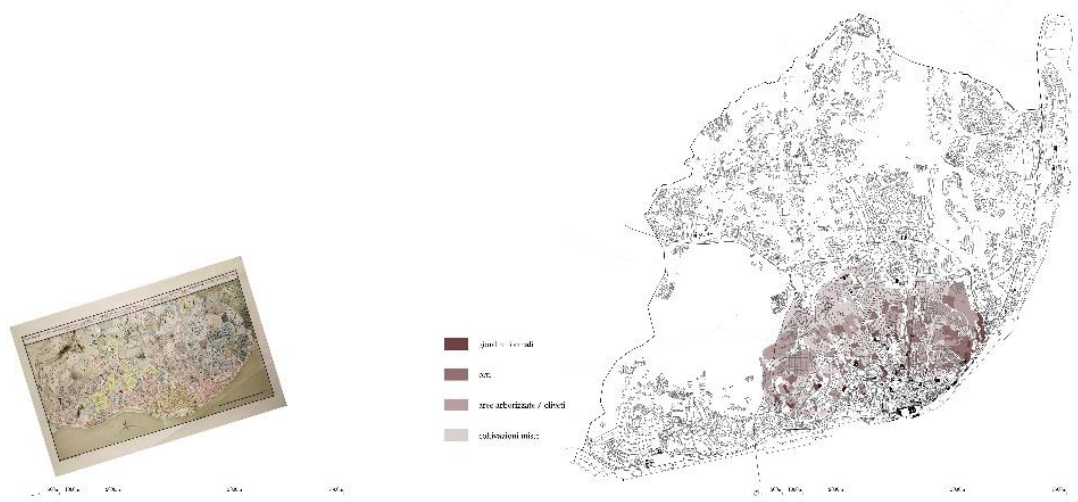

Figura 3 - Ocupação agrícola Lisboa no século XVIII. Informação cartográfica retirada de: Planta Topográfica da Cidade de Lisboa, comprendendo na sua extensão abeira mar da Ponte de d'Alcantara até ao Convento das Comendadeiras de Santos [...] [Material Cartográfico]. [s.l.: s.n., s.d.]. - 1 planta ms.: color.; 152 x $68 \mathrm{~cm}$. Col. Vieira da Silva. 

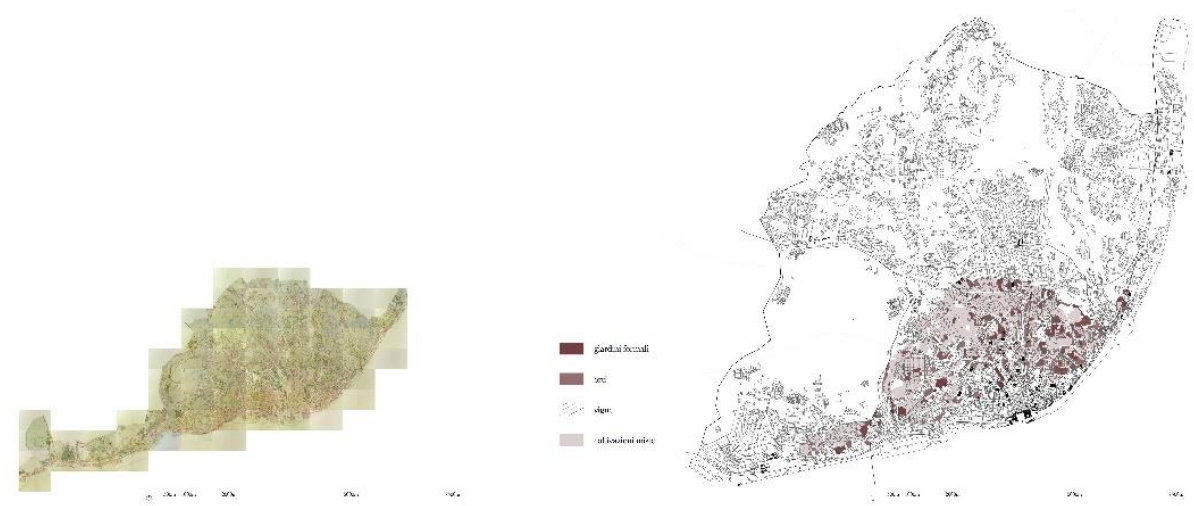

Figura 4 - Ocupação agrícola de Lisboa na segunda metade do século XIX. Informação cartográfica retirada de: FOLQUE, Filipe - Levantamento de Lisboa de 1856 / dir. Filipe Folque [Material Cartográfico]. - Escala 1:5000. [S.I.: s.n.; 1859]. - 65 plantas ms.: color. Arquivo da Câmara Municipal de Lisboa.

\section{A paisagem agrícola do campo}

$\mathrm{Na}$ zona Norte-Oriental, onde os terrenos eram particularmente férteis, o território estava organizado em vastas propriedades agrícolas denominadas quintas, lugares de produção que circundavam a cidade e alimentavam a crescente população urbana $e$ suburbana (RIBEIRO, 1994 [1935]: 23). Com o passar do tempo, as quintas assumiram o carácter de lugares amenos dedicados ao ócio, onde as famílias mais abastadas se refugiavam nos quentes meses de estio. Assim nasciam, no século XVI, as denominadas quintas de recreio que, de seiscentas, passaram no espaço de um século para mais de duas mil. Eram propriedades organizadas de um modo racional, cuja posição no território atendia à qualidade do solo e às condições atmosféricas específicas do lugar, integrando um bosque (mata), uma área dedicada à produção onde habitualmente se encontravam plantações de laranjeiras, oliveiras e vinha (pomar/horta), e também um jardim de carácter mais representativo e formal (horto de recreio) (TELLES, 2011b: 157).

$\mathrm{Na}$ descrição que nos faz da ocupação do solo no território português no início do século XVII, a Corografia Portuguesa ${ }^{4}$, reporta-nos a existência, em Lisboa, de "muytas quintas nobres" (COSTA, 1712: 419) na paróquia dos Anjos - que se estendia desde a zona de Arroios até à atual Alameda -, e também nas paróquias de São Sebastião da Pedreira (atual zona das Avenidas Novas) e de São José (atual Freguesia de Santo António), onde havia "quatorze hortas [...] \& muytas quintas" (COSTA, 1712: 432).

No século XVI, o humanista português Damião de Góis escrevia:

"O territorio da cidade, para qualquer ponto para onde se volte a vista, está povoado de casas de recreio e quintas, com edifícios magníficos, por causa da abundância da terra [...] Os campos, por tôda a parte, também estão matizados de casa de campo e aldeias e igrejas e conventos, tão belos e em tão grande número que as quintas e casas de 
campo, nas redondezas, vão além de seiscentas." (GÓIS, s.d.: 55)

Também os terrenos para lá do Tejo que se avistavam a partir das colinas eram descritos como vastas planícies cobertas de campos de trigo, onde o rendimento agrícola era tal, que chegavam a ser ainda mais férteis que os campos mais próximos à cidade. (GÓIS, s.d.: 56).

Um século mais tarde, também o clérigo Frei d'Oliveyra nos trazia a imagem de uma cintura produtiva repleta de "un numero quasi infinito" ${ }^{\text {de }}$ quintas que se estendia para lá dos limites terrestres da cidade, mas também para lá do rio, entre Cacilhas e a Trafaria, por sobre um território completamente cobertos de pomares, vinhas e searas (D'OLIVEYRA, 1804: 145-146).

De facto, não era possível abastecer a cidade a cidade contando apenas com a produção no interior do seu território pelo que, todos os dias, um incessante fluxo de carros, qual um rio perene de tão copioso, chegava às principais portas da cidade: Porta da Cruz, a oriente; Porta da Esperança, a ocidente; e Porta da Mouraria e de Porta de Santo Antão, a norte. Os carros chegavam cheios e partiam vazios, transportando bens de primeira necessidade, como trigo, cevada, vinho, azeite, frutas e verduras, que eram produzidos nas numerosas quintas e hortas que circundavam a cidade, mas também leite, manteiga e caça, abundantes ao longo de todo o ano. ${ }^{6}$ Contudo, não faltavam hortas urbanas dentro de portas (duzentas e setenta segundo a contagem de d'Oliveyra), cujos proventos eram vendidos em bancas de mercado, espalhadas pela cidade. A abundância de hortícolas era tal, que o governo da cidade estabeleceu uma lei segundo a qual só podiam ser vendidos diariamente os produtos que tivessem sido colhidos no próprio dia (D'OLIVEYRA, 1804: 192).

\section{A entrada na cidade: entre cultivado e construído}

Luís Mendes de Vasconcelos descrevia, no século XVII, o modo como a produção agrícola, desenvolvida sobretudo nos vales, se estendia desde a periferia até quase ao coração da cidade. O perímetro murado da cidade, erigido em 1375 por ordem do rei D. Fernando e denominado de Cerca Nova, atravessava a Colina de Sant'Anna, e infletia, junto ao Rossio, na direção de dois vales férteis, cobertos de hortas e almuinhas (RIBEIRO, 1994 [1935]: 84-85). As principais entradas na cidade estavam posicionadas no alinhamento dos vales, nas zonas onde os campos agrícolas penetravam o território urbanizado: Arroios e Andaluz a norte, Enxobregas - atual Xabregas - a oriente, e Alcântara a ocidente (VASCONCELOS, 1786: 135). Espaço construído e espaço cultivado coincidiam de tal modo que era por vezes difícil definir uma fronteira clara entre cidade e campo.

O autor do Livro das Grandezas de Lisboa, descrevia-nos o caminho de entrada na cidade a partir do oriente, como uma estrada que corria paralelamente ao rio, bordejada de "riquissimas hortas, e quintas" (D'OLIVEYRA, 1804: 187). Do mesmo modo, para chegar à cidade vindo do ocidente, percorria-se um caminho ladeado de "rendosissimas quintas", que passava pela zona de Alcântara, "povoada de algumas quintas, e hortas com muytas fontes, de que saem abundantissimas agoas" (D'OLIVEYRA, 1804: 220). Este troço ocidental, entre Belém e a entrada na cidade, 
tinha já sido descrito por Damião de Góis, um século antes, como um território ameno, onde quintas suburbanas de admirável elegância, e vastas extensões de campos e pomares, cativavam o olhar dos passantes (GÓIS, s.d.: 39).

Por sua vez, a chegada ao centro da cidade a partir do norte era feita por caminhos que corriam ao longo de dois vales fecundos, cobertos de hortas, que ladeavam a colina de Sant'Anna.

\section{A paisagem urbana e a atividade agrícola ao longo dos vales}

A Baixa de Lisboa, situada entre a colina do Castelo e a colina de São Roque e coração da cidade de Lisboa na atualidade, situa-se no ponto onde, no passado, confluíam duas férteis linhas de vale: o vale ocidental, antigo vale de Valverde e leito da atual Avenida da Liberdade; e o oriental, correspondente à zona da Mouraria, onde hoje correm a Rua da Palma e a Avenida Almirante Reis (D'OLIVEYRA, 1804: 118).

Falando do vale de Valverde, Luís Mendes de Vasconcelos descrevia-nos no século XVII, o troço compreendido entre o Vale da Nunciada e Andaluzes (VASCONCELOS, 1786: 161) como um lugar onde as casas se encontravam imersas num manto verde repleto de hortas e moinhos de vento. Antes dele, também Damião de Góis havia relatado como, descendo da Igreja de São Roque na direção do atual Largo da Anunciada, nos deparávamos com um território coberto de jardins e pomares:

"Depois, continuando o mesmo trajecto, faz-se a descida a um vale muito ameno, contíguo às muralhas da cidade, plantado de hortas por todos os lados». Na vertente oriental do vale, erguia-se a colina de Sant'Anna, cujo declive estava coberto de «um olival tão denso que a vista mal pode penetrar lá dentro." (GÓIS, s.d.: 40)

Do lado oposto da colina, descia-se na direção de um segundo vale tão fértil quanto o primeiro, denominado de vale da Mouraria, cintado pelo lado do oriente pelas colinas do Castelo, Graça, Senhora do Monte e Penha de França. Aqui, as culturas eram irrigadas por uma corrente de água que descia do Areeiro, ora em torrente, ora em canais subterrâneos (AZEVEDO, 1899-1900: 221). A abundância de água fazia com que o vale e as suas vertentes pululassem de hortas, cada uma com o seu poço, na maioria dos casos (AZEVEDO, 1899-1900: 257). Numa atenta descrição do sistema hídrico da zona compreendida entre o Areeiro e a Mouraria, Pedro de Azevedo citava um antigo documento datado de 1685, onde era referido o cano do chafariz d'Arroyos: um canal de encanamento de água que, depois da Igreja dos Anjos, «abaixo do chafariz se mette por entre as hortas», prolongando-se até à Baixa (AZEVEDO, 18991900: 223-224). Em tempos idos, esta corrente do fundo do vale, denominada de Rego ou Regueirão, chegaria provavelmente até ao Rossio, ponto onde se ligava às águas que chegavam do Andaluz, através do vale de Valverde (AZEVEDO, 1899-1900: 221).

O vale da Mouraria, situado fora de portas, era um território rico em hortas, mas também em terras lavradas e olivais (Figuras 5 e 6) ${ }^{7}$. Documentação antiga dá-nos conta da presença de almuinhas, logo à saída da porta de São Vicente ${ }^{8}$, que se estendiam depois pelo fundo do vale, ao longo da artéria principal que levava até ao campo. Outras descrições, datadas dos séculos XVI e XVII, reportam-nos também a 


\section{estudoprévio}

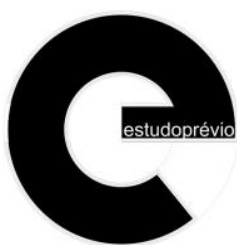

PT | P01 | EP18| w2021

existência de hortas no vale de São Jordão (correspondente ao vale da Mouraria) localizado no território compreendido entre a entrada da Rua do Benformoso e a Igreja de Santa Bárbara (atual Largo de Santa Bárbara) (AZEVEDO, 1899-1900: 278). Aquela que é hoje a zona do Intendente, por exemplo, era no ano de 1442 uma grande horta - a Horta da Laranjeira -, implantada no local onde veio a ser construído no século XVI o mosteiro do Desterro, convertido depois em hospital e parcialmente demolido, para permitir a passagem da Avenida Almirante Reis.

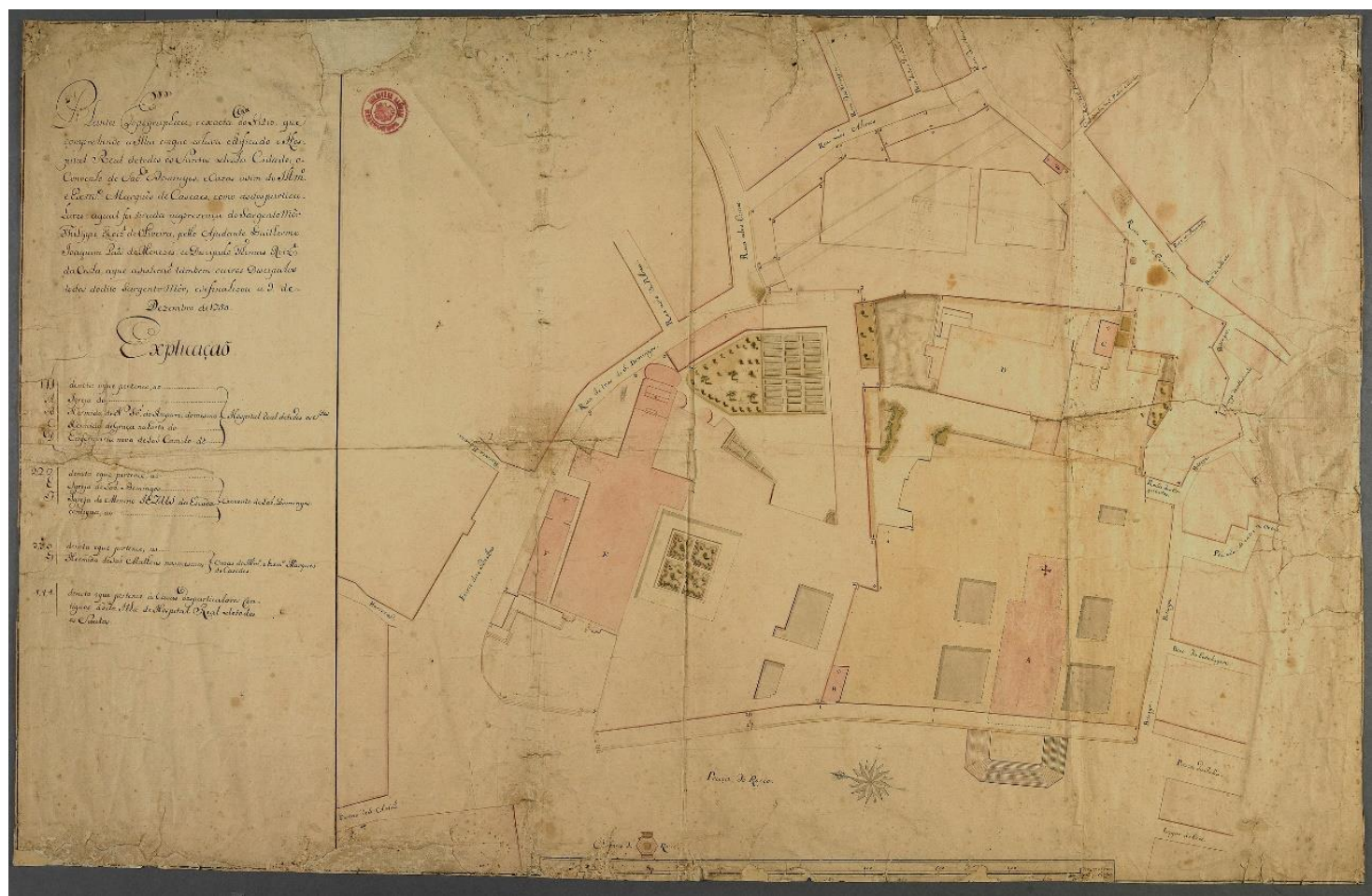

Figura 5 - Planta Topographica, e exacta do sitio, que compreende a ilha em que estava edificado o Hospital Real de Todos os Santos desta cidade, o Convento de São Domingos e cazas assim do Illustrissimo e Excelentissimo o Marquês de Cascaes, como as dos particulares [Material cartográfico] / a qual foi tirada na presença do Sargento- Môr Philippe Rodrigues de Oliveira, pelo Ajudante Guilherme Joaquim Paês de Meneses, e o discípulo Thomas Rodrigues da Costa a que assistirão também outros Discípulos do dito Sargento-mor, e que nalizou a 9 de Dezembro de 1750. Disponível em: http://purl.pt/22488 


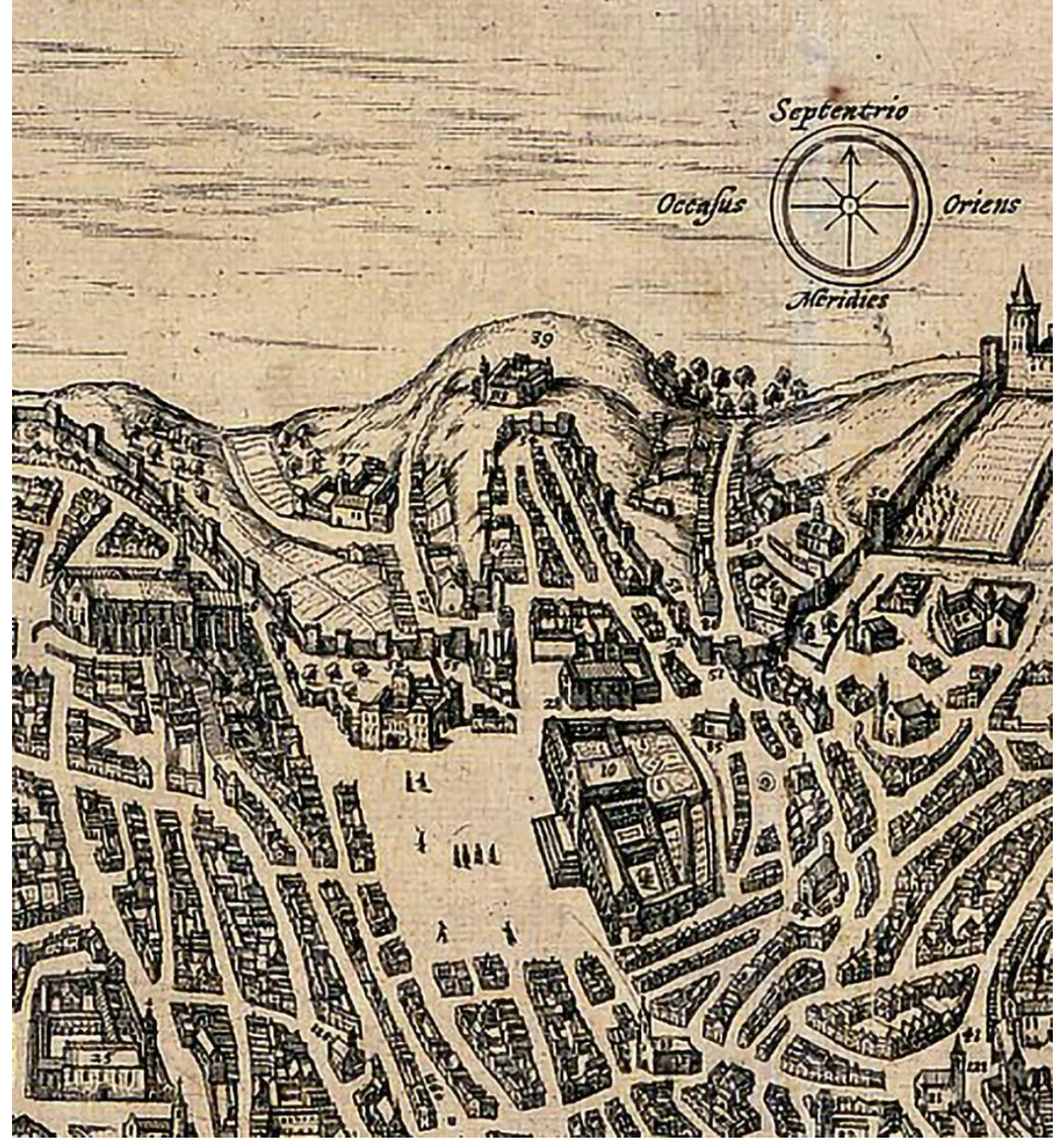

Figura 6 - Detalhe que mostra o sistema de vales a convergir na Praça do Rossio, onde de erguia o Hospital de Todos-os-Santos com as suas hortas. Xilografia de 1593. Autor: Franz Hogenberg. Disponível em:

https://es.wikipedia.org/wiki/Sitio_de_Lisboa_\%281384\%29\#/media/Archivo:Lisbon_in_1598.jpg

Chegados às portas da cidade, a produção agrícola continuava, em hortas que se estendiam como um manto verde, do vale da Mouraria até à Baixa. A Cerca Nova "atravessava no valle unicamente almoinhas e nas encostas olivaes" (AZEVEDO, 1899-1900: 258) que, no ano de 1461, ainda chegavam até à zona da Praça da Palha (Travessa da Palha, hoje Rua dos Correeiros), situada na atual Baixa (AZEVEDO, 1899-1900: 215). Além disso, vários escritos datados dos séculos XIV e XV atestavam a existência de numerosas almuinhas, para além de pátios ricos em hortícolas e de árvores de fruto, na zona da atual Praça do Rossio e Praça da Figueira (AZEVEDO, 1899-1900: 258), no lugar onde se situava o antigo mosteiro de São Domingos ${ }^{9}$. Em 1424, o olival e as hortas pertencentes a este complexo eclesiástico estendiam-se por sobre o vasto terreno fértil compreendido entre as portas de Sant'Antão e de São Vicente e por volta do final do século, o Hospital de Todos os Santos era construído sobre as antigas almuinhas do mosteiro, no lugar da atual Praça da Figueira (AZEVEDO, 1899-1900: 224). Destruído pelo terramoto de 1755, não restam hoje 
PT | P01 | EP18| w2021

vestígios deste edifício que era, à época, o maior hospital de Lisboa, e em cujo perímetro encontrávamos, em pleno centro da cidade, várias hortas, conforme relata Damião de Góis, no século XVI - "Está o edificio dividido em quatro alas, com hortos aprazíveis" (GÓIS, s.d.: 46) e, mais tarde, Frei d'Oliveyra - "tem [...] huma grande horta com muyta agoa, naqual (além das hortaliças, que se nella produz) ha dous grandes tanques" (D'OLIVEYRA, 1804: 223).

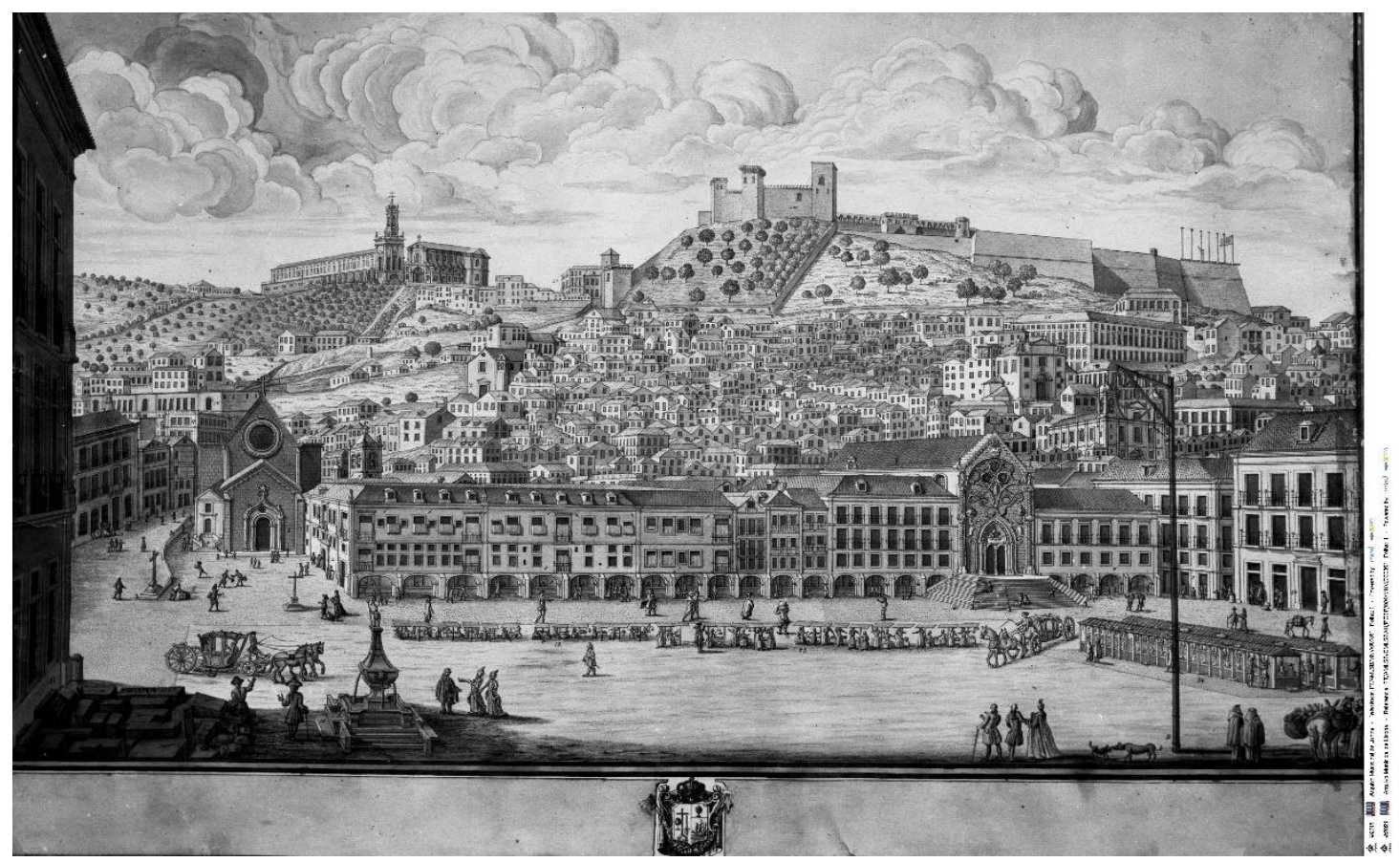

Figura 7 - Rossio antes do terramoto de 1755. Água-tinta, desenho à pena a nanquim de Zuzarte, século XVIII]. Fonte: Arquivo Fotográfico Municipal de Lisboa, PT/AMLSB/CMLSBAH/PCSP/004/MNV/000361.
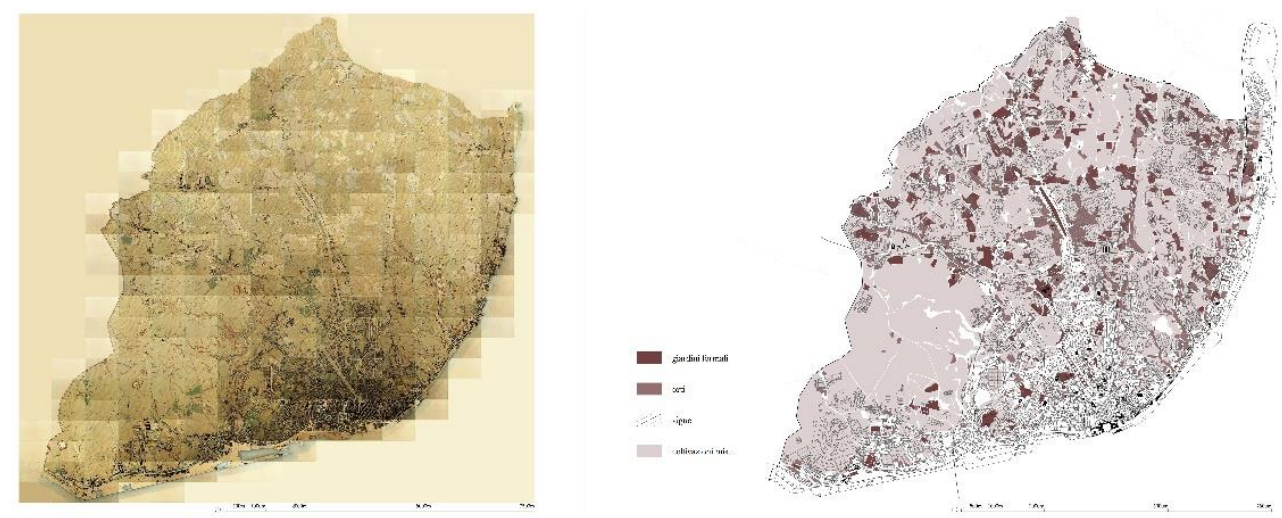

Figura 8 - Ocupação agrícola em Lisboa no início de Novecentos. Informação cartográfica retirada de: PINTO, [Julio António Vieira da] Silva - Levantamento Topográfico de Lisboa em 1904 - 1911 / dir. [Júlio António Vieira da] Silva Pinto [Material Cartográfico]. - Escala 1:1000. Fonte: Arquivo da Câmara Municipal de Lisboa. Base cartográfica: reelaboração gráfica da autora a partir da Carta de Lisboa realizada por Inês Lobo arquitectos. 
PT | P01 | EP18| w2021

Situado na convergência de dois vales férteis, em pleno coração da cidade, o vizinho Rossio, guardou por muito tempo um forte carácter agrícola, que se manteve mesmo após a reestruturação de que foi objeto no século XVIII. Na realidade, a reconstrução pós-terramoto, mais não fez que confirmar a importância do papel deste lugar assim como o do Terreiro do Paço, enquanto pontos de articulação do tecido urbano: o Terreiro do Paço, enquanto praça "aberta para o mar"; e o Rossio, circundado de colinas, aberto "para as hortas, quintas e olivais dos arredores" (RIBEIRO, 1994 [1935]: 103-104) ${ }^{10}$ (Figura 8). No final do século, também o relato de Link nos dá conta da esplêndida vista que se desfrutava a partir da Colina de São Roque, em que se contemplava "à esquerda os olivais, quintas, igrejas e conventos disperses, em frente a colina alta e íngreme onde se encontra o castelo, à direita o Tejo" (LINK, 2005: 104). De facto, no centro da cidade, os declives mais pronunciados, e que não eram por isso adequados, nem para a construção, nem para o cultivo de hortícolas, estavam normalmente cobertos de olivais, plantados durante o reinado de D. Fernando (13671383) (AZEVEDO, 1899-1900: 258). e parcialmente erradicados, no século XVI, por ordem de $\mathrm{D}$. Manuel, que considerava que estes davam um uma imagem demasiado provinciana da capital (RIBEIRO, 1994 [1935]: 14-15).

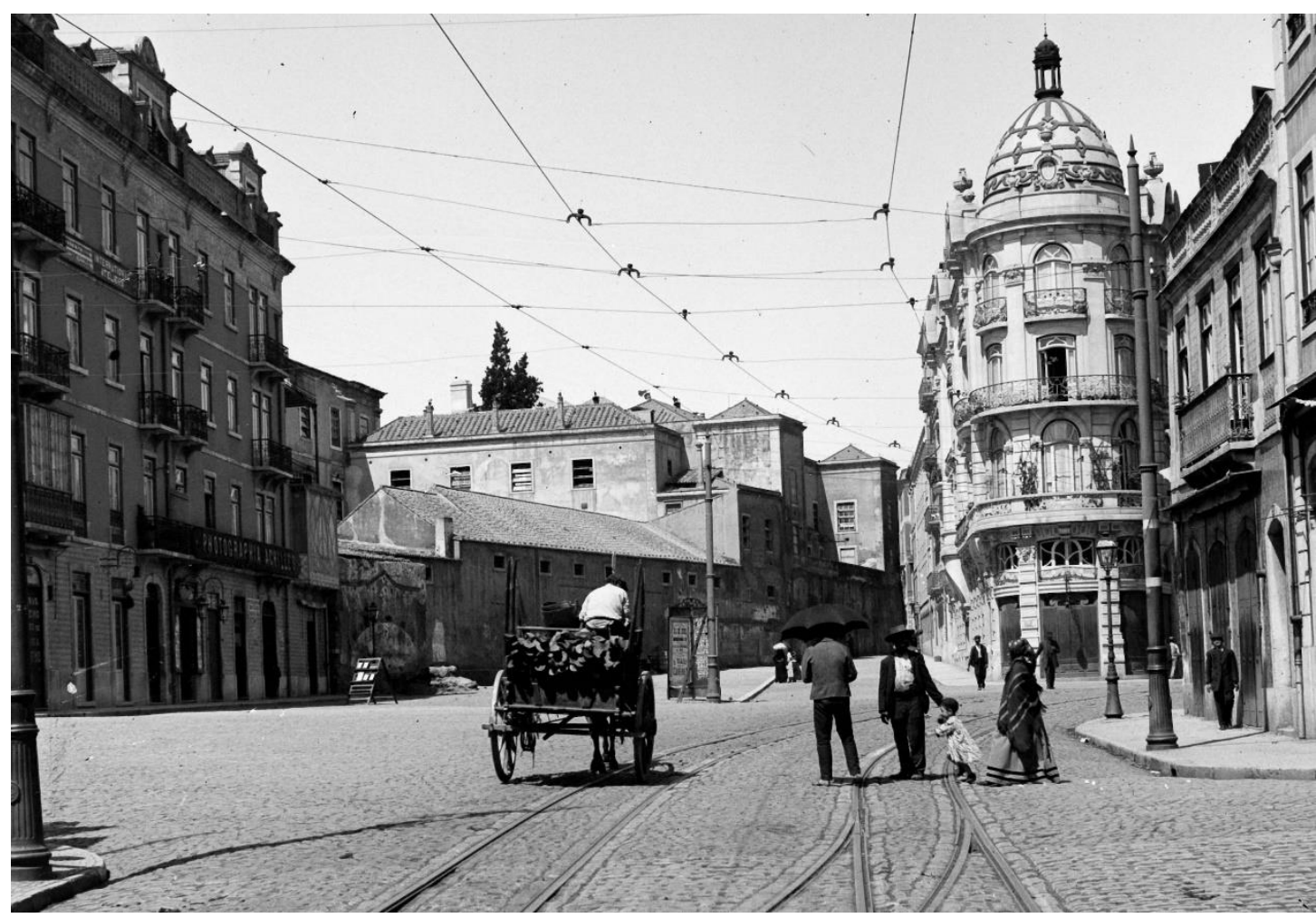

Figura 9 - Carro que transporta hortaliças na Avenida Almirante Reis, diante do mosteiro de Nossa Senhora do Desterro, [191?]. Autor: Joshua Benoliel. Fonte: Arquivo Fotográfico Municipal de Lisboa, PT/AMLSB/CMLSBAH/PCSP/004/JBN/000652.

Alguns vestígios destas pendentes arborizadas permaneceram visíveis até à segunda metade do século, momento em que a cidade passou por uma importante fase de expansão. Segundo descrição de Orlando Ribeiro no ano de 1935, quem estivesse na Praça do Rossio, podia ainda avistar olivais nas encostas das colinas, entre o Castelo 
e a Penha de França, "quase com a mesma fisionomia fixada nas velhas gravuras" (RIBEIRO, 1994 [1935]: 14-15).

\section{A toponímia das rua}

O autor de Do Sítio de Lisboa dava também conta da existência de vários moinhos de vento na zona do Rossio, junto a São Pedro de Alcântara (VASCONCELOS, 1786: 161). Implantados nas elevações, normalmente associados a vastos campos de trigo, os moinhos eram outro elemento tipicamente rural que marcava a imagem da cidade. Desaparecidos na sua maior parte, suplantados pela pressão urbana do último século, os moinhos sobrevivem topónimos, como a Calçada do Moinho de Vento na Colina de Sant'Anna, a Travessa do Moinho de Vento na Ajuda, a Travessa do Moinho de Vento na zona da Lapa, a Travessa dos Moinhos em Alcântara ou a Rua dos Sete Moinhos em Campo de Ourique. Com efeito, a toponímia da cidade na actualidade constitui um testemunho evidente da interpenetração entre rural e urbano que historicamente marcou a fisionomia da cidade, pelo modo como foi mantendo, até hoje, nomes de elementos pertencentes ao mundo agrícola como árvores, vinhas ou culturas hortícolas, que desapareceram com a recente expansão urbana (RIBEIRO, 1949: 4).

Em 1804, a lista dos topónimos contidos no Itinerário Lisbonense, reenviava-nos para uma imagem ainda rústica da cidade, com os seus nomes de ruas derivados de um léxico agrícola, mas também pela presença de numerosas quintas, terrenos de cultivo e azinhagas (caminho murado típico da paisagem rural) (Itinerário Lisbonense, 1804) Na descrição de Lisboa contida n' O Mappa De Portúgal Antigo E Moderno, datado de 1763, encontramos também referência a topónimos como a Rua do Pocinho dentre as Hortas, uma antiga artéria da Baixa, desaparecida na sequência do terramoto de 1755 (CASTRO, 1763: 321). A freguesia de S. José, instituída em 1567, foi originalmente denominada de São José de Entre as Hortas, nela se localizando a ermida homónima, construída em 1546, fora da antiga cerca muralhada de Lisboa, por entre as quintas, hortas e olivais que então existiam naquela zona da cidade, junto às Portas de Sant'Antão. Nas imediações, encontramos ainda menção, no referido texto de 1763 a uma Rua Horta dos Ulmeiros, topónimo que vem confirmar que, pouco mais de cem anos antes, "a mayor parte desta freguezia erão matos cerrados com algmas hortas, olivaes e quintas" (CASTRO, 1763: 283). ${ }^{11}$ Também na colina do Bairro Alto, que no século XV era ainda um campo, o nome das ruas remete ainda hoje para uma organização agrícola do território: Rua do Loureiro, Rua da Vinha, Rua da Horta Seca, Travessa da Horta (RIBEIRO, 1994 [1935]: 14-15). Do mesmo modo, a Travessa das Hortas da Cera, localizada junto à antiga Valverde e Hortas de S. José (entre a Rua do Salitre e a Avenida da Liberdade), recordam os campos cultivados que caracterizaram a zona até ao final do século XIX. Finalmente, no fértil vale de Alcântara, antigo lugar de terras de cultivo e de hortas no limite ocidental da cidade, a Travessa da Horta Navia representa hoje um testemunho deste passado agrícola, no preciso lugar onde estava localizada a quinta homónima, implantada num terreno fecundo, irrigado pelo Rio d'Alcântara. 
PT | P01 | EP18| w2021

\section{A expansão urbana dos séculos $\mathrm{XIX}$ e $\mathrm{XX}$}

A Revolução industrial e a consequente fase de crescimento urbano pela qual passou a cidade de Lisboa a partir da segunda metade do século XIX, marcaram o declínio da prática agrícola no território. Os vestígios que ainda restavam de um passado agrícola tornaram-se cada vez mais raros, ao mesmo tempo que o tecido urbano se estendia, das áreas centrais da cidade na direção das antigas paisagens rurais:

"Os moinhos de vento que coroavam as elevações, as hortas (culturas hortícolas) com o seu sábio sistema de irrigação, as vinhas, os olivais e os campos de cereais, desaparecem sob um manto uniforme de ruas e casas." (RIBEIRO, 1949: 14-15)

À medida que a pressão urbana se intensificava, os amplos espaços afectos à produção agrícola eram gradualmente empurrados para a periferia, conforme nos revela o Levantamento da Planta de Lisboa coordenado por Silva Pinto (1904-1911). Este conjunto de mapas mostra uma área produtiva organizada em torno de quintas, propriedades agrícolas e de uma estrutura territorial predominantemente rural. As hortas, as vinhas e os olivais concentravam-se sobretudo na zona oriental, enquanto que a ocidente predominavam as culturas extensivas e campos de terra lavrada (MARAT-MENDES et al, 2015) (Figura 10). Nesse momento, o mundo agrícola mantinha ainda uma relação próxima com o espaço urbano, que dele dependia para o abastecimento de alimentos (SALVADOR; OLIVEIRA, 2015).

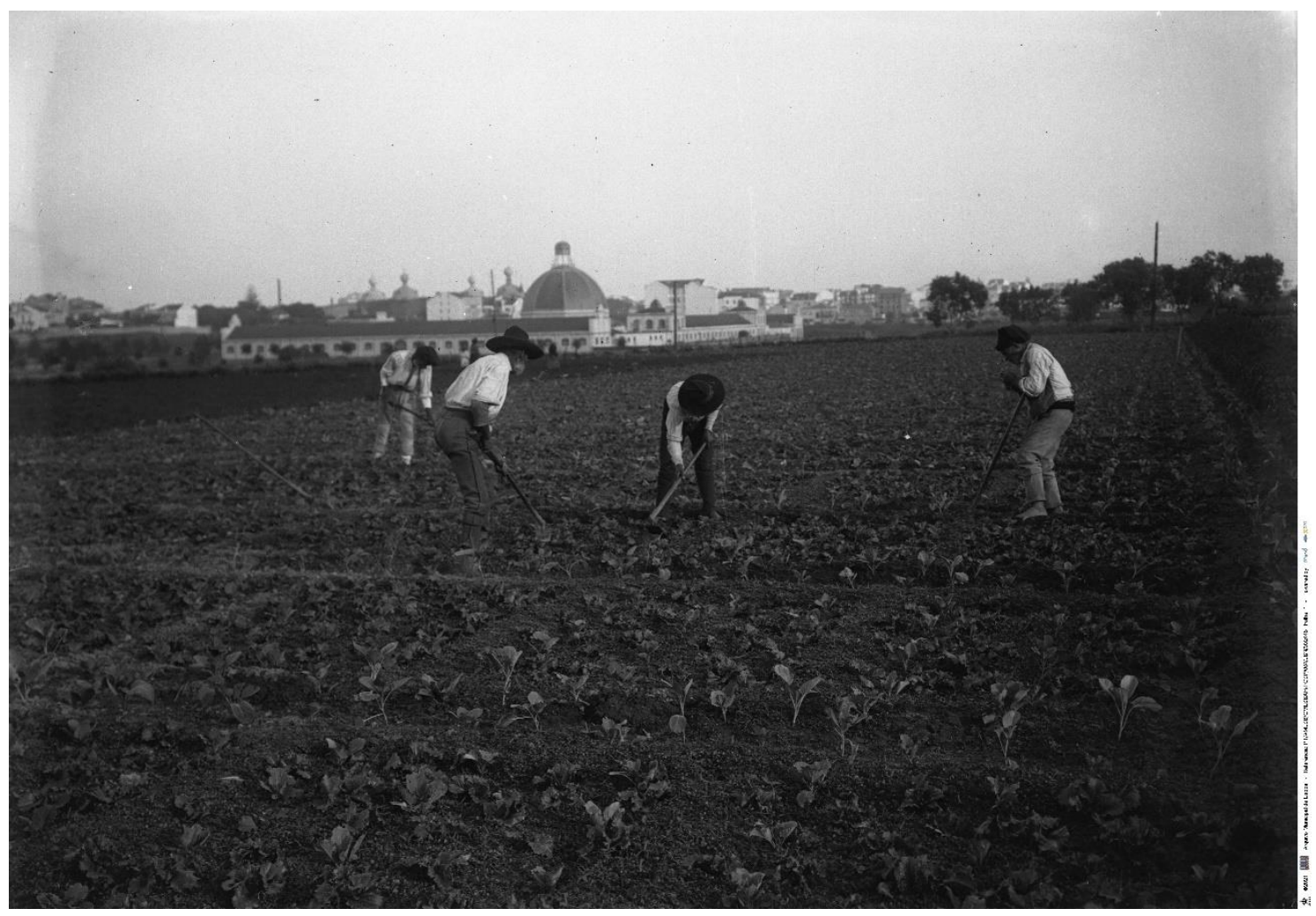

Figura 10 - Trabalhadores agrícolas junto ao Mercado Geral de Gados na zona de Alvalade, c. 1910. Autor: Joshua Benoliel. Fonte: Arquivo Fotográfico Municipal de Lisboa, PT/AMLSB/CMLSBAH/PCSP/004/JBN/002448. 


\section{estudoprévio}

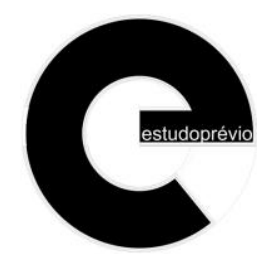

PT | P01 | EP18| w2021

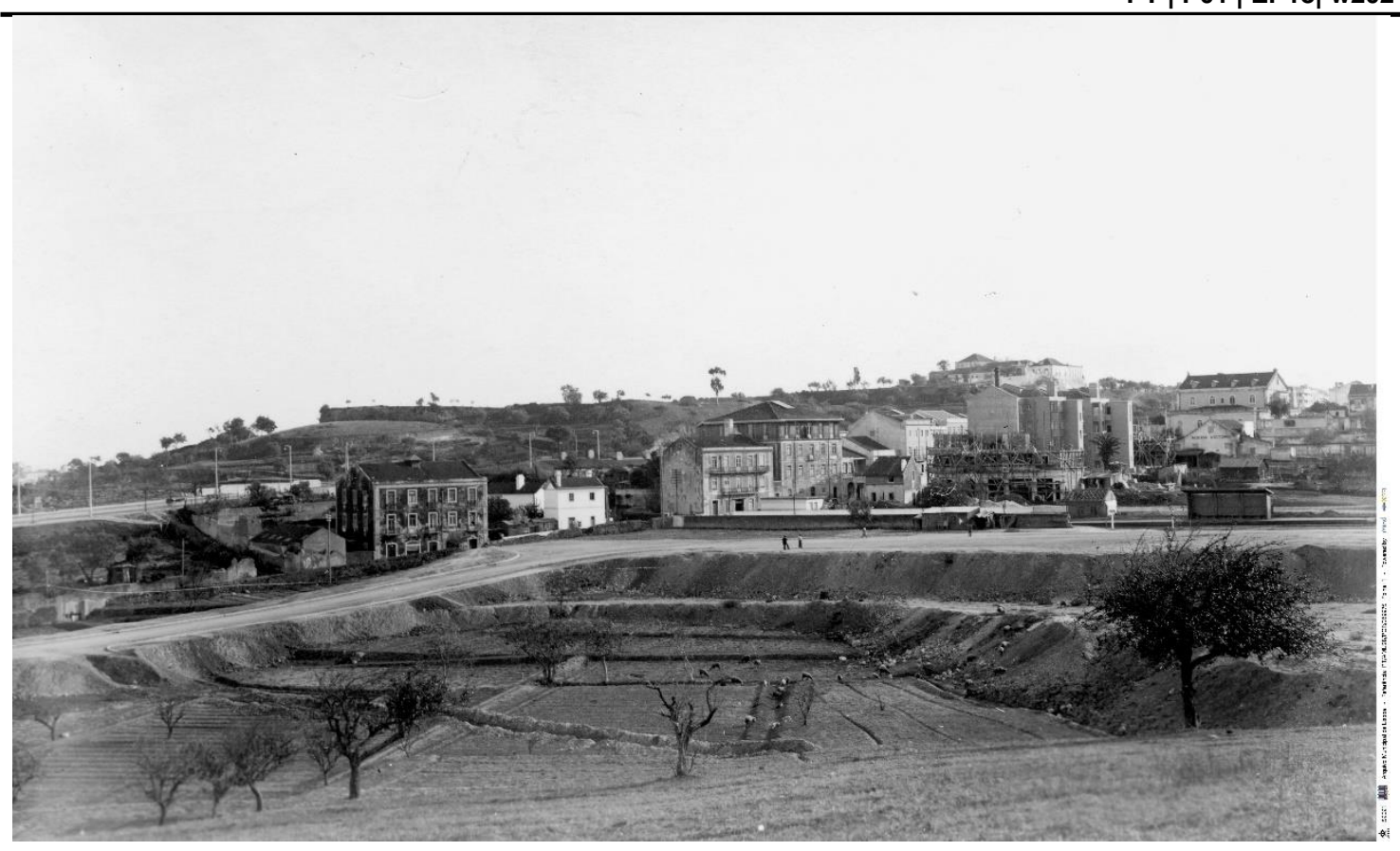

Figura 11 - Panorâmica sobre a zona do Areeiro tirada dos Lagares d'El Rei, 1947. Autor: Eduardo Portugal. Fonte: Arquivo Fotográfico Municipal de Lisboa, PT/AMLSB/POR/059975.

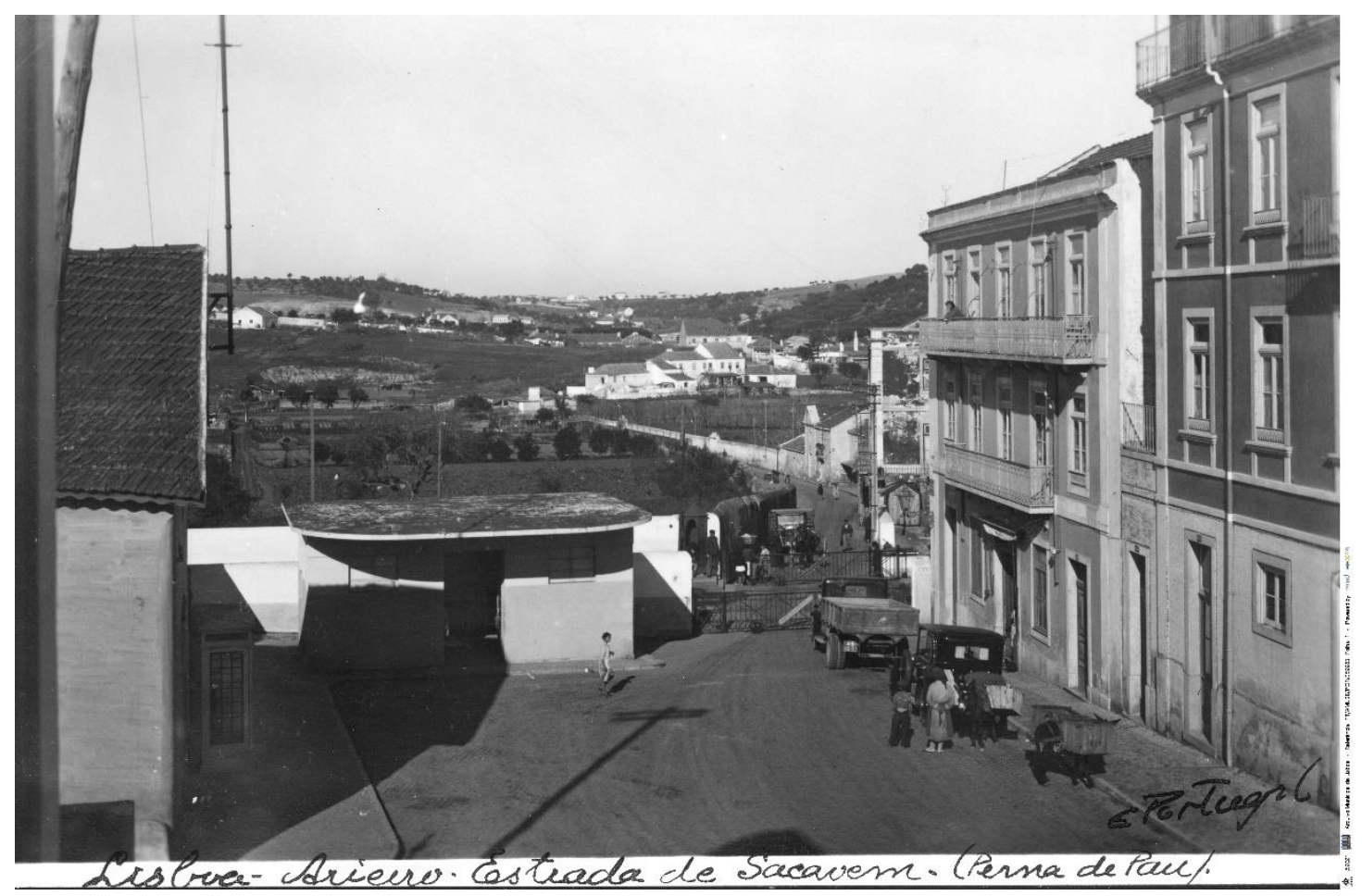

Figura 12 - Passagem de nível na Estrada de Sacavém, ao Areeiro, perto do retiro A Perna de Pau, Lisboa, c. 1938. Autor: Eduardo Portugal. Fonte: Arquivo Fotográfico Municipal de Lisboa, PT/AMLSB/POR/059983. 
PT | P01 | EP18| w2021

O vale de Chelas, por exemplo, descrito já no século XVII como lugar "ameno para a recreaçaõ, \& abundante pela fertilidade de seus frutos" (COSTA, 1712: 374), ainda guardava um carácter marcadamente agrícola, na primeira metade do século XX, com as suas hortas, olivais e vinhas, de onde provinham produtos que eram consumidos em Lisboa. Orlando Ribeiro traçava uma singular imagem da Lisboa dos anos 30, que dá conta da proximidade que existia entre espaço produtivo e consumidor: lentos carros de bois carregados de produtos agrícolas, que reenviam para um cenário rural, desciam na direcção do frenético centro urbano, atravessado por automóveis e eléctricos, elementos da metrópole em expansão (RIBEIRO, 1994 [1935]: 14-15). Também na zona de Arroios, Arco do Cego e Areeiro, onde o território esteve organizado em torno de grandes quintas até ao fim do século XIX, hortas e campos cultivados coexistiram, lado a lado com as novas edificações, antes de serem completamente esmagados pela pressão urbana (Figuras 11 e 12). Em 1935, Orlando Ribeiro afirmava:

"recordo-me de ter visto uma nora ao lado de um grande prédio acabado de construir; e o vasto edifício do Instituto Superior Técnico está em grande parte ainda rodeado de hortas." (RIBEIRO, 1994 [1935]: 21).

Naqueles anos, Lisboa passava por mudanças rápidas, em que as áreas urbanizadas ganhavam terreno, sobrepondo-se às paisagens rurais:

"a actividade construtiva tende a eliminar, e tem eliminado, os antigos elementos campestres. Estes vestígios são cada dia mais raros e dentro em pouco desaparecerão totalmente ou é preciso procurá-los mais longe. Quem deseje ver como as coisas se passam pode subir a Avenida Almirante Reis e ao topo, para as bandas do Areeiro, observe como a azinhaga, a horta, a nora, a casa de campo e os seus anexos, são substituídos pelo prédio alto e grande". (RIBEIRO, 1994 [1935]: 15).

Na sua dinâmica de expansão, a cidade estendeu-se na direcção do planalto, mas veio também ocupar os férteis vales de Alcântara, Valverde e Chelas, correspondentes às actuais Avenida de Ceuta, Avenida da Liberdade e Estrada de Chelas, cuja urbanização decorre da expropriação de antigas propriedades agrícolas e hortas (GRAÇA; SEQUEIRA, 2019: 13). Aos limites das antigas propriedades agrícolas veio sobrepor-se a nova lógica de fragmentação em lotes dos novos bairros, ao mesmo tempo que os campos cultivados e as hortas que existiam junto às construções do centro da cidade desapareciam ou eram englobados na estrutura urbana. Alguns foram convertidos em quintais - nome dado aos jardins privados associados às habitações -, incorporados no interior dos blocos residenciais das Avenidas Novas (TELLES, 2011b: 157), ou nos logradouros da malha urbana do novo bairro de Alvalade (TELLES, 1997: 69). Ao mesmo tempo, os olivais e vinhas que em tempos povoavam as colinas do centro da cidade desapareciam, não deixando senão tímidos vestígios sobre os declives mais acentuados. Com a redução das áreas cultivadas no solo citadino (Figura 13), o número de empregados do sector agrícola diminuiu drasticamente no interior da área administrativa de Lisboa, passando das 7400 pessoas em 1925 ${ }^{12}$, para as 685 em 2011 (dados Pordata). 


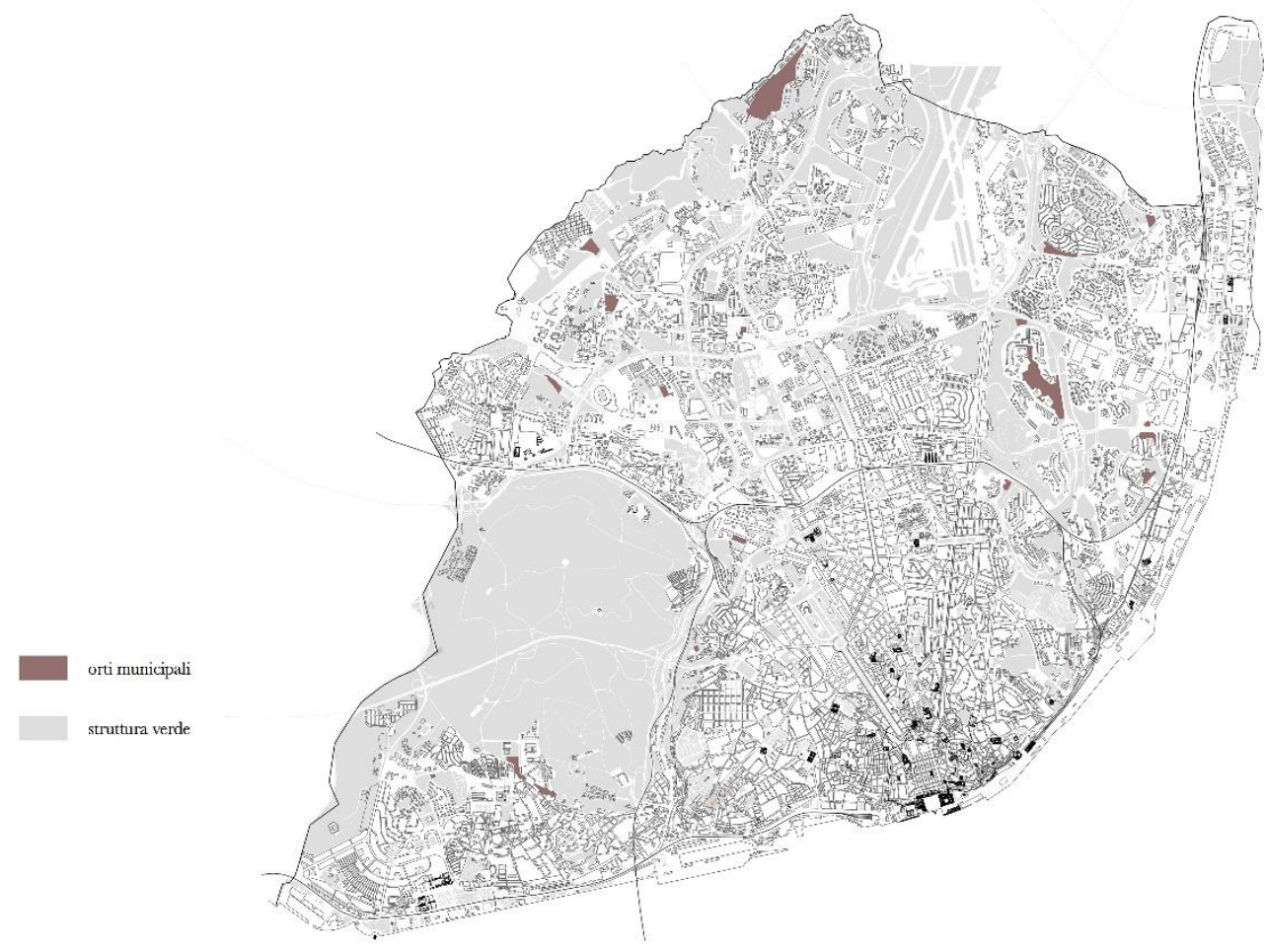

Figura 13 - Mapa verde atual de Lisboa

Disponível em: http://Ixi.cm- lisboa.pt//xi/ Base cartográfica: reelaboração gráfica da autora a partir da Carta de Lisboa realizada pela Inês Lobo arquitectos.

\section{Recuperar a agricultura urbana em Lisboa hoje}

A transformação do espaço cultivado em espaço edificado ocorreu de forma repentina, sem que fossem estabelecidos, na maior parte dos casos, planos coerentes que tivessem em conta as condições naturais do lugar, e o seu passado agrícola (TELLES, 2011b: 51). Muitas áreas urbanas de construção recente mostram ainda marcas evidentes de uma antiga ocupação rural: velhas casas de campo decadentes e antigas instalações agrícolas existem lado a lado com grandes viadutos e vias de grande circulação automóvel, condomínios e complexos industriais. Estes serão por isso lugares particularmente aptos a acolher, hoje, estratégias de recuperação do uso agrícola do território, mas também da característica interpenetração entre o mundo rural e o mundo urbano, que encontramos na Lisboa antiga. De facto, desde há alguns anos, estão em curso nas zonas de recente expansão da cidade programas públicos que procuram incentivar um regresso à actividade agrícola dentro da capital: a Câmara Municipal de Lisboa é proprietária de um conjunto de talhões que aluga a pequenos produtores, incentivando assim o cultivo e o consumo de produtos agroalimentares de produção local.

A singular relação que a cidade, ao longo da história, foi estabelecendo com as condições naturais do lugar, como o clima, a geologia e o relevo, tornam-na um lugar 
único (TELLES, 2011b: 46). Este deve ser o ponto de partida para uma mais integrada gestão da paisagem que seja também capaz de recuperar, mais de um século depois do advento da Revolução Industrial, a unidade entre urbe e ager: "Sempre que é possível, a horta cola-se à habitação como que seja uma dependência, tão íntima como a cozinha e tão agarrada a ela como o quarto de dormir" (ARAÚJO, 2011: 99). Da escala da horta privada nas traseiras da casa até uma escala urbana mais ampla, a atividade agrícola torna-se assim numa oportunidade de requalificar a cidade a partir daquilo que esta tem de mais singular, aproximando produtor e consumidor, e deste modo reencontrando uma conexão física, ecológica e cultural com a natureza e a paisagem rural envolvente.

\section{Bibliografia}

ARAÚJO, llídio de - A paisagem do futuro, Jubilação do professor Gonçalo Ribeiro Telles, Universidade de Évora, 1992. In Textos escolhidos. Lisboa: Argumentum, 2011 , p. 99.

AZEVEDO, Pedro de - Do Areeiro à Mouraria (Topographia Historica de Lisboa). O Arqueólogo Português, 1. e série, vol. V, Lisboa, 1899-1900, p. 212-224 e 257-279.

CASTRO, João Bautista de, Mapa De Portúgal Antigo E Moderno, Tomo terceiro, Parte V, Lisboa: na officina Patriarcal de Francisco Luiz Ameno, 1763.

Censo extraordinário da população das cidades de Lisboa e Porto: 1 de Dezembro de 1925. Ministério das Finanças, Direcção-Geral de Estatística. Lisboa: Imprensa Nacional, 1926.

COSTA, António Carvalho da - Corografia portugueza e descripçam topografica do famoso reino de Portugal, com as noticias das fundações das Cidades, Villas,\& Lugares, que contem Varões ilustres, Geneologias das Familias nobres, fundações de Conventos, Catalogos de Bispos, antiguidades, maravilhas da natureza, edificios, \& outras curiosas observaçoens. Tomo III. Lisboa: Oficina de Valentim da Costa Deslandes, 1712.

D'OLIVEYRA, Nicolao - Livro das grandezas de Lisboa. Lisboa: Impressão regia, 1804.

FRANÇA, José-Augusto - Lisboa: urbanismo e arquitetura. Lisboa: Instituto de Cultura e Língua Portuguesa - Ministério da Educação e Ciência, 1980.

GÓIS, Damião de - Descrição da cidade de Lisboa pelo cavaleiro português Damião de Góis, Fundação Mário Soares / DFL - Documentos Felicidade Alves. Disponível em: http://www.casacomum.org/cc/visualizador?pasta=07466.005.001 [Consult. 22/04/20].

GRAÇA, João Luís Carrilho; SEQUEIRA, Marta - Lisbona: civiltà e territorio. Rassegna di Architettura e Urbanistica: Lisbona.Trasformazioni urbane negli anni della crisi, Anno LIV, número 159, setembro-dezembro 2019, p. 9-15.

GONÇALVES, Luís Ribeiro, Sistemas de circulação de água e poder na Lisboa medieval - séculos XIV a XVI, tesi magistale in História Medieval. Lisboa: Faculdade de Letras da Universidade de Lisboa, 2011.

GONÇALVES, Luís Ribeiro - Sistemas de circulação de água e poder na Lisboa medieval - séculos XIV a XVI. Cadernos do Arquivo Municipal. 2ª Série, N. 8 (julho - dezembro 2017), p. 37 - 54. 
Itinerário Lisbonense, Ou Directorio Geral de Todas As Ruas, Travessas, Becos, Calçadas, Praças, Etc., Que se Comprehendem no Recinto da Cidade de Lisboa: para utilidade, uso, e commodidade dos estrangeiros, e nacionaes. Lisboa: Impressão regia, $1804 . \quad$ Disponível em: https://archive.org/details/itinerariolisbon00mora/page/20/mode/2up; [Consult. 28/04/20].

LINK, Heinrich Friedrich - Notas de uma viagem a Portugal e através de França e Espanha. Lisboa: Biblioteca Nacional Portugal, 2005.

Lisboa interativa, Câmara Municipal de Lisboa. Diponível em: http://xi.cm- lisboa.pt/lxi/ [Consult. 20/06/20].

MARAT-MENDES, Teresa; MOURÃO, Joana; d'ALMEIDA, Patrícia Bento; NIZA, Samuel - Water and Agriculture Atlas: Lisbon Region 1900-1940. ISCTE-IUL, 2015. DOI: 10.15847/pm.2015.001 Disponível em: https://repositorio.iscteiul.pt/handle/10071/8985 [Consult. 25/06/2020].

MARAT-MENDES, Teresa; BENTO D'ALMEIDA, Patrícia; MOURÃO, Joana; NIZA, Samuel; FERREIRA, Daniela - Mapping Lisbon agriculture (1898-1911). In Cities of Europe, Cities of the World, vol. 1. 2014. Disponível em: https://memoproject.files.wordpress.com/2014/12/mapping-lisbonagriculture_23_07_2014.pdf [Consult. 25/06/2020].

Memo Project - Evolution of the Lisbon metropolitan area metabolism. Lessons towards a Sustainable Urban Future, 2014. Disponível em: https://memoproject. wordpress.com [Consult. 15/07/2020].

MOYA, Ana - Sustentabilidade sociocultural na paisagem urbana histórica e multicultural no Bairro da Mouraria, Lisboa. Revista de Geografia e Ordenamento do Território (GOT), número 17, junho 2019, Centro de Estudos de Geografia e Ordenamento do Território, p. 179-199.

Pordata, Base de dados Portugal Contemporâneo. Disponível em: www.pordata.pt(Acedido em 15/12/20)

Pordata, Base de dados Portugal Contemporâneo, « Resident population: total and by major age groups". https://www.pordata.pt/en/Municipalities/Resident+population+total+and+by+maj or+age+groups-390 [Consult. 15/12/2020].

RIBEIRO, Orlando - O sítio e o crescimento de Lisboa. Terra Brasilis (Nova Série). In Congresso Internacional de Geografia, Lisboa: 1949 [Comunicação apresentada à Association de Géographes Français e publicada no seu Bulletin, Paris, 1938]. Disponível em: http://journals.openedition.org/ terrabrasilis/737 [Consult. em 0105-20].

RIBEIRO, Orlando - Lisboa, Génese de uma capital. Opúsculos Geográficos V. Temas Urbanos. Lisboa: Fundação Calouste Gulbenkian, 1994 [Texto redigido em dezembro de 1935, retomado pelo autor em 1963].

RIBEIRO, Orlando - O crescimento de Lisboa. Opúsculos Geográficos V. Temas Urbanos. Lisboa: Fundação Calouste Gulbenkian, 1994, p. 13-18 [texto redigido em dezembro de 1935, retomado pelo autor em 1963].

SALVADOR, Mariana Sanchez, OLIVEIRA, M.R. - O Abastecimento Alimentar de Lisboa: Perspectivas do Passado. In Valores da Geografia. Atas do X Congresso da Geografia Portuguesa. Lisboa: Associação Portuguesa de Geógrafos, 2015, 182-187.

TELLES, Gonçalo Ribeiro - A paisagem do futuro. Jubilação do Professor Gonçalo Ribeiro Telles, Universidade de Évora, 1992. In Textos escolhidos. Lisboa: 
Argumentum, 2011.

TELLES, Gonçalo Ribeiro - Quintas e quintais de Lisboa. In Textos escolhidos. Lisboa: Argumentum, 2011.

TELLES, Gonçalo Ribeiro - Plano Verde de Lisboa. Lisboa: Colibri, 1997.

VASCONCELOS, Luís Mendes de - Do Sítio de Lisboa, Sua Grandeza, Povoação, e Commercio, \&c.: Diálogos, Reimpressos conforme a ed. de 1608, novamente correctos e emendados. Lisboa: Officina Patr. de Francisco Luiz Ameno, 1786.

VITERBO, Joaquim de Santa Rosa de - Elucidário das palavras, termos e frases que em Portugal antigamente se usaram e que hoje regularmente se ignoram. Lisboa: Officina di Simão Thaddeo Ferreira, 1798, vol. 1, p. 102-103. Disponível em: https://purl.pt/28511/1/index.html\#/18-19/html

1 O presente artigo é parte integrante de uma dissertação de Mestrado em Arquitetura, que propunha uma reflexão acerca da relação entre alimentação e espaço urbano, através da elaboração de uma solução arquitetónica contemporânea capaz de recuperar a ancestral proximidade na relação entre os universos urbano e agrícola na cidade de Lisboa, perdida nos últimos séculos.

2 O domínio romano em Lisboa durou cerca de 600 anos, desde 205 a.C. momento em que Olisipo se torna parte da República romana, até 410 d.C. quando a se iniciam os saques pelos bárbaros. ${ }^{3}$ Durante a ocupação árabe contavam-se cerca de 150000 pessoas a trabalhar na agricultura e no comércio, dentro e fora da cerca muralhada (FRANÇA, 1980).

${ }^{4}$ Para um levantamento das quintas existentes no território de Lisboa no início do século XVII, ver: António Carvalho da Costa (COSTA, 1712, Tomo III. pp. 339-545).

5 "não escreuendo as quintas, nem ermidas, que dentro deste circulo se contem, que seria dar hum numero quasi infinto" (D'OLIVEYRA, 1804: 145-146).

6 "e como hum perenne Rio está isto continuamente correndo sem cessar" (D'OLIVEYRA, 1804: 159-160).

7 Para uma recolha de descrições antigas das hortas existentes no Vale da Mouraria consultar: Pedro de Azevedo (AZEVEDO, 1899-1900: 257-279).

8 "Almoynha com sua cassa que he acerca da porta de san Bicente da dita cidade ffora do muro". (AZEVEDO, 1899-1900: 268).

9 "hua almoynha que $\mathrm{o}$ ito moesteiro ha dentro na cerca da dita cidade a qual he antre o muro e canos da porta de sam Bicente e o moesteiro de sam Domingos cõ suas cassas direitos e pertenças que parte com o dito muro e olyual do dito moesteiro de sam Domingos e cõ o caminho que bae arredor da dita almoynha de sam Domingos pera a porta de sam Bicente" (AZEVEDO, 1899-1900: 260).

10 "o núcleo da cidade passa a ser a Baixa, enquadrada por duas formosas praças, uma aberta para o mar - o Terreiro do Paço - e outra para as hortas, quintas e olivais dos arredores - 0 Rossio" (RIBEIRO, 1994 [1935]: 103-109).

11 "Há pouco mais de cem annos, que a mayor parte desta freguezia erão matos cerrados com algmas hortas, olivaes, e quintas. Hoje esta summamente povoado o seu districto" (CASTRO, 1763: 283).

12 A actividade agrícola ocupava 1,4\% da população. Os habitantes de Lisboa eram $529524 \mathrm{em}$ 1925. Fonte: Censo extraordinário da população das cidades de Lisboa e Porto: 1 de dezembro de 1925 / Ministério das Finanças, Direcção Geral de Estatística. Imprensa Nacional, 1926 (RIBEIRO, 1994 [1935]: 21). 